\title{
Analisis Kemampuan Berbahasa dan Penanaman Moral pada Anak Usia Dini melalui Metode Mendongeng
}

\author{
Putri Hana Pebriana ${ }^{凶}$ \\ Universitas Pahlawan Tuanku Tambusai
}

\begin{abstract}
Abstrak
Faktor yang sangat penting bagi anak dalam mengekspresikan emosinya adalah melalui bahasa. Selain itu, penanaman moral juga harus ditanamkan pada anak sejak dini. Bahasa bagi anak dapat diperoleh melalui pengalamannya dalam kehidupan sehari-hari. Pada fase ini, anak mengalami tahap perkembangan bahasa yang dapat dikatakan bisa berkembang dengan pesat apabila metode yang dipilih dalam proses pembelajaran juga tepat. Salah satu metode yang dapat menjadi alternatif dalam mengembangkan bahasa bagi anak usia dini adalah dengan menggunakan metode mendongeng. Secara tidak langsung melalui kegiatan mendengarkan anak dapat menyerap informasi yang ada pada cerita. Mendengarkan dongeng mencakup penambahan kosakata baru dalam unsur cerita juga pesan moral, sehingga dengan metode ini anak dengan mudah menerima penambahan kosakata baru dan juga pesan moral yang terkandung dalam sebuah cerita. Melalui mendongeng maka secara otomatis akan terjadi transformasi nilai melalui tingkah laku dan karakter tokoh yang ada dalam cerita. Dari pemaparan yang telah dijabarkan bahwa metode mendongeng selain dapat mengembangkan kemampuan berbahasa anak, metode ini juga dapat dijadikan alternatif dalam menanamkan moral pada anak.
\end{abstract}

Kata Kunci: Kemampuan Berbahasa, Penanaman Moral, Metode Mendongeng

\begin{abstract}
A very important factor for the child in expressing his emotions is through language. In addition, moral planting should also be implanted in children from an early age. Language for children can be obtained through experience in everyday life. In this phase, the child experiences a stage of language development that can be said to grow rapidly if the method chosen in the learning process is also appropriate. One method that can be an alternative in developing the language for early childhood is to use the method of storytelling. Indirectly through listening activities children can absorb the information that is on the story. Listening to fairy tales involves adding new vocabulary in story elements as well as moral messages, so by this method the child easily accepts the addition of new vocabulary as well as the moral message contained in a story. Through storytelling it will automatically happen value transformation through the behavior and character of the characters in the story. From the exposure that has been described that the method of storytelling in addition to developing language skills of children, this method can also be used as an alternative in instilling moral in children.
\end{abstract}

Keywords: Language Ability, Moral Planting, Storytelling Method

@ Jurnal Obsesi Prodi PG-PAUD FIP UPTT 2017

$\triangle$ Corresponding author :

Address : Bangkinang,Riau, Indonesia

Email : Putripebriana99@gmail.com

ISSN 2356-1327 (Media Cetak)

ISSN 2549-8959 (Media Online)

PENDAHULUAN 
Anak usia dini merupakan seseorang yang sedang mengalami proses pekembangan yang sangat pesat dan fundamental untuk kehidupan selanjutnya. Anak usia dini memiliki rentang umur dari 0-8 tahun. Pada masa ini, anak memiliki ciri khas dalam bertingkah laku. Pada dasarnya pertumbuhan dan perkembangan anak pada usia ini pertumbuhan menjadi dasar dalam menentukan arah pekembangan anak selanjutnya. Hal ini diperkuat menurut pendapat Mansur (2005:88) anak usia dini adalah kelompok anak yang berada dalam proses pertumbuhan dan perkembangan yang bersifat unik. Mereka memiliki pola pertumbuhan dan perkembangan yang khusus sesuai dengan tingkat pertumbuhan dan perkembangannya. Pada masa ini merupakan masa emas atau golden age, karena anak mengalami pertumbuhan dan perkembangan yang sangat pesat dan tidak tergantikan pada masa mendatang. Menurut berbagai penelitian di bidang neurologi terbukti bahwa 50\% kecerdasan anak terbentuk dalam kurun waktu 4 tahun pertama. Setelah anak berusia 8 tahun perkembangan otaknya mencapai $80 \%$ dan pada usia 18 tahun mencapai $100 \%$ (Suyanto, 2005: 6). Selain itu Rusdinal (2005: 16) menambahkan bahwa karakteristik anak usia 5-7 tahun adalah sebagai berikut: 1) anak pada masa praoperasional, belajar melalui pengalaman konkret dan dengan orientasi dan tujuan sesaat, 2) anak suka menyebutkan nama-nama benda yang ada disekitarnya dan mendefinisikan kata, 3) anak belajar melalui bahasa lisan dan pada masa ini berkembang pesat, 4) anak memerlukan struktur kegiatan yang lebih jelas dan spesifik.

Perkembangan bahasa pada anak usia dini merupakan salah satu faktor yang memepengaruhi perkembangan kognitif anak. Semakin anak tumbuh dan berkembang serta mulai mampu memahami lingkungan maka perkembangan bahasa pun semakin berkembang dari tingkat yang sederhana menuju tingkat yang paling kompleks.
Perkembangan bahasa sangat dipengaruhi oleh faktor lingkungan, karena pemerolehan bahasa itu secara tidak langsung diperoleh melalui lingkungan. Menurut Lenneberg perkembangan bahasa anak berjalan sesuai jadwal biologisnya (Eni Z, 2003: 13). Hal ini dapat digunakan sebagai dasar mengapa anak pada umur tertentu sudah dapat berbicara, sedangkan pada umur tertentu belum dapat berbicara. Perkembangan bahasa tidaklah ditentukan. pada umur, namun mengarah pada perkembangan motoriknya. Namun perkembangan tersebut sangat dipengaruhi oleh lingkungan. Bahasa anak akan muncul dan berkembang melalui berbagai situasi interaksi sosial dengan orang dewasa (Kartini Kartono, 1995: 127). Bahasa memiliki peranan yang sangat penting dalam kehidupan seharihari. Suhartono (2005: 13-14) menyatakan bahwa peranan bahasa bagi anak usia dini diantaranya sebagai sarana untuk berfikir, sarana untuk mendengarkan, sarana untuk berbicara dan sarana agar anak mampu membaca dan menulis. Melalui bahasa seseorang dapat menyampaikan keinginan dan pendapatnya kepada orang lain.

Berkaitan dengan perkembangan bahasa, permasalahan yang sering sekali terjadi di TK/KB bahwa anak masih mengalami kesulitan dalam berbahasa. Hal ini dikarenakan ada beberapa hal yang menjadi penyebab terjadinya permasalahan tersebut yaitu anak kurang baik dalam pengucapan kata/huruf, kurang tepat dan kurang lancar dalam mengucap kata selain itu dalam pembelajaran bahasa guru cenderung menganggap dirinya sebagai sumber pengetahuan, metode yang digunakan juga masih bersifat konvensional dan kurang bervariasi dalam menerapkan metode pembelajaran. Berdasarkan hasil pengamatan yang dilakukan oleh peneliti, maka diperlukan metode yang cocok atau sesuai dengan permasalahan yang terjadi yaitu metode mendongeng. Pemberian dongeng terhadap kemampuan bahasa sangat erat kaitannya, karena dengan pemberian dongeng anak mendapatkan pengetahuan dengan melalui proses asimilasi yaitu 
anak mengevaluasi dan mencoba memahami informasi baru, berdasarkan pengetahuan dunia yang sudah dimiliki (Upton, 2012).

Selain itu, metode mendongeng juga dapat diterapkan untuk menanamkan moral pada anak usia dini. Moral sangat penting diterapkan sejak usia dini, karena moral sangat menentukan karakter yang akan dibentuk baik atau buruk pada anak. Berkaitan dengan moral banyak sekali permasalahan yang terjadi di Indonesia ini. Permasalahan yang terjadi terkait dengan moral ini di Indonesia hampir tiap hari disajikan televisi melalui siaran berita, seperti kasus pemerkosaan, tawuran dan tindakan-tindakan kriminal yang seringkali meneyebabkan jatuhnya korban, baik itu korban luka-luka hingga berujung kematian. Yang membuat lebih miris dari semua itu adalah usia para pelaku yang masih berstatus pelajar. Maka dari itu diperlukan solusi ataupun aternatif yang cocok terkait pembelajaran pada anak usia dini agar kemampuan berbahasa pada anak usia dini dapat dikembangkan dan penanaman moral dapat dilakukan melalui metode mendongeng.

Maka dari itu, peneliti tertarik untuk melakukan penelitian tentang Analisis Kemampuan Berbahasa dan Penanaman Moral pada Anak Usia Dini Melalui Metode Mendongeng.

\section{Karakteristik Kemampuan Berbahasa Anak Usia Dini}

Brewer (dalam Lamuningtyas, 2012) memamparkan bahwa bahasa merupakan suatu sistem komunikasi yang digunakan oleh manusia, baik yang dihasilkan atau disampaikan secara lisan melalui isyarat yang dapat diperluas kedalam bentuk tulisan. Selain itu menurut (Jahja, 2011) kemampuan bahasa merupakan kemampuan untuk berkomunikasi dengan orang lain yang mencakup semua cara untuk berkomunikasi, dimana pikiran dan perasaan dinyatakan dalam bentuk lambang atau simbol untuk mengungkapkan suatu pengertian seperti dengan menggunakan lisan, tulisan, isyarat, bilangan, lukisan, dan mimik muka.

Banyak aspek yang menjadi karakteristik perkembangan bahasa pada anak, dimana aspek-aspek ini perlu untuk diperhatikan lebih mendalam, agar perkembangan bahasa anak berkembang sesuai tahapannya. Pengembangan kemampuan bahasa meliputi pengembangan aspek mendengar, berbicara, menulis, dan membaca. Berdasarkan karakteristik anak usia dini, aspek kemampuan bahasa yang paling utama dikembangkan adalah kemampuan mendengar dan berbicara (Wiyani, 2014).

Beberapa karakteristik kemampuan bahasa anak usia 5-6 tahun Papilla, Olds, dan Fledman (2008), Hetherington dan Park, Carey dan Clark (dalam Santrock, 2011), yaitu; a) Sudah dapat mengucapkan lebih dari 2.600 kata, b) kalimat anak mencapai enam sampai delapan kata, c) memahami lebih dari 20.000 kata, d) Sudah dapat berkomunikasi dengan jelas, e) Dapat menjelaskan arti kata-kata yang sederhana, f) Dapat menggunakan kata penghubung, kata depan, dan kata sandang, g) Lingkup kosakata yang dapat diucapkan anak menyangkut warna, ukuran, bentuk, rasa, bau, keindahan, kecepatan, suhu, perbedaan, perbandingan, jarak, dan permukaan (kasar atau halus), h) Mengenal banyak huruf, i) Dapat melakukan peran sebagai pendengar yang baik, j) Mampu berpartisipasi dalam suatu percakapan, k) Percakapan yang dilakukan oleh anak telah menyangkut berbagai komentar terhadap apa yang dilakukan oleh dirinya sendiri, orang lain serta apa yang dilihatnya, 1) Anak usia 5-6 tahun mampu melakukan ekspresi diri, menulis, membaca, bahkan berpuisi.

Adapun tingkat pencapaian perkembangan bahasa pada anak usia dini terutama pada anak usia 5-6 tahun yang telah disusun oleh badan nasional sertifikasi profesi (BNSP) sesuai dengan karakteristik perkembangan bahasa anak (Wiyani, 2014), yaitu; a) Menyusun kalimat sederhana dalam struktur yang lengkap (pokok kalimat-predikat 
keterangan), b) Terlibat dalam pemilihan dan memutuskan aktivitas yang akan dilakukan bersama temannya, c) Perbendaharaan kata lebih kaya dan lengkap untuk melakukan komunikasi verbal.

\section{Penanaman Moral pada Anak Usia Dini}

Kata moral berasal dari bahasa Latin mos (jamak mores) yang berarti kebiasaan, adat (Bertens, 1993). Berns (1997) mengemukakan bahwa moralitas mencakup mematuhi aturan sosial dalam kehidupan sehari-hari dan conscience atau aturan personal seseorang untuk berinteraksi dengan orang lain.

Moral berasal dari kata Latin mores yang artinya tata cara dalam kehidupan, adat istiadat, kebiasaan. Moral pada dasarnya merupakan rangkaian nilai tentang berbagai macam perilaku yang harus dipatuhi. Moral merupakan kaidah norma dan pranata yang mengatur perilaku individu dalam hubungannya dengan kelompok sosial dan masyarakat. Moral merupakan standard baik-buruk yang ditentukan bagi individu nilainilai sosial budaya dimana individu sebagai anggota sosial. Moralitas merupakan aspek kepribadian yang diperlukan seseorang dalam kaitannya dengan kehidupan sosial secara harmonis, adil, dan seimbang. Perilaku moral diperlukan demi terwujudnya kehidupan yang damai penuh keteraturan, ketertiban, dan keharmonisan.

Menurut Piaget perkembangan moral terjadi dalam dua tahapan, yaitu tahap pertama adalah "tahap realisme moral" atau "moralitas oleh pembatasan" dan tahap kedua "tahap moralitas

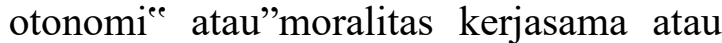
hubungan timbal balik". (Hurlock, 1978:79). Dalam tahap pertama, peerilaku anak ditentukan oleh ketaatan otomatis terhadap peraturan tanpa penalaran atau penilaian. Mereka menganggap orang tua dan semua orang dewasa yang berwenang sebagai maha kuasa dan mengikuti peraturan yang diberikan pada mereka tanpa mempertanyakan kebenarannya.
Dalam tahap ini anak menilai tindakannya benar atau salah berdasarkan konsekuensinya dan bukan berdasarkan motivasi di belakangnya. Mereka sama sekali mengabaikan tujuan tindakannya tersebut. Dalam tahap kedua, anak menilai perilaku atas dasar tujuan yang mendasarinya. Tahap ini biasanya dimulai antara usia 7 atau 8 tahun dan berlanjut hingga usia 12 tahun atau lebih. Gagasan yang kaku dan tidak luwes tentang benar salah perilaku mulai dimodifikasi. Anak mulai mempertimbangkan keadaan tertentu yang berkaitan dengan suatu pelanggaran moral.

\section{Metode Mendongeng}

Dongeng adalah cerita yang tidak benar-benar terjadi dan dalam banyak hal sering tidak masuk akal (Nurgiantoro, 2005:198). Pendapat lain mengenai dongeng adalah cerita yang tidak benarbenar terjadi, terutama tentang kejadian zaman dulu yang aneh-aneh (Alwi H, 2007:274). Agus D.S (2008: 14) yang disebut dengan mendongeng adalah kegiatan bercerita atau menuturkan cerita secara lisan. Masyarakat Indonesia sudah mengenal dongeng sejak zaman dahulu. Mereka mendongeng sambil bersifat religi. Kegiatan mendongeng kemudian diambil alih oleh orang tua, pengasuh, kakek dan nenek. Dongeng berkembang terus baik bentuk maupun ciri-cirinya. Mendongeng harus dilakukan dengan cara-cara yang benar seperti orang tua yang sedang memberi nasehat kepada anak yaitu dengan cara lemah lembut dan kasih sayang.

\section{Macam-macam dongeng}

Anti Aarne dan Stith Thompson (Danandjaja, 2007:86) telah membagi jenis-jenis dongeng ke dalam empat golongan besar. Keempat golongan tersebut adalah sebagai berikut : 1 . Dongeng Binatang (animal tales) Dongeng binatang adalah dongeng yang ditokohi binatang peliharaan dan binatang liar. Binatang-binatang tersebut dalam cerita jenis ini dapat berbicara dan berakal budi seperti manusia. 2. Dongeng Biasa 
(ordinary tales) Dongeng biasa adalah jenis dongeng yang ditokohi manusia dan biasanya adalah kisah suka duka seseorang. a. Dongeng mengenai ilmu sihir (tales of magic) b. Dongeng keagamaan (religious tales) c. Ceritacerita roman (romantic tales) d. Dongeng mengenai raksasa bodoh (tales of stupid agre) 12 3. Lelucon dan anekdot (jokes and anecdotes) Lelucon dan anekdot adalah dongeng yang dapat menimbulkan rasa menggelikan hati. Ada sedikit perbedaan antara lelucon dan anekdot. Lelucon menyangkut kisah fiktif lucu anggota suatu kolektif, seperti suku bangsa, golongan, bangsa atau ras. Sedangkan anekdot menyangkut kisah fiktif lucu pribadi seorang tokoh atau beberapa tokoh yang benar-benar ada. 4 . Dongeng Berumus Dongeng yang strukturnya terdiri dari pengulangan. Dongeng-dongeng berumus mempunyai beberapa sub bentuk, yakni: dongeng bertimbun banyak, dongeng untuk mempermainkan orang, dongeng yang tidak mempunyai akhir (Bruvand dalam Danandjaja, 2007:139).

Sedangkan Stewig (Nurgiyantoro, 2005:201) membagi jenis dongeng dilihat dari waktu kemunculannya yaitu dongeng klasik dan dongeng modern. Dongeng klasik adalah cerita dongeng yang telah muncul sejak zaman dahulu yang telah mewaris secara turun temurun lewat tradisi lisan. Sedangkan dongeng modern adalah cerita dongeng yang sengaja ditulis untuk maksud bercerita dan agar tulisannya itu dibaca oleh orang lain. Jadi dongeng modern secara jelas ditunjukkan pengarang, penerbit, dan tahun.

\section{METODE}

Penelitian ini menggunakan kajian pustaka, kajian pustaka dalam suatu penelitian ilmiah adalah salah satu bagian penting dari keseluruhan langkah-langkah metode penelitian. Menurut Zed (2004) mengemukakan riset pustaka tidak hanya sekedar urusan membaca dan mencatat literatur atau buku-buku sebagaimana yang sering dipahami banyak orang selama ini apa yang disebut riset pustaka atau sering disebut studi pustaka, ialah rangkaian kegiatan yang berkenaan dengan metode pengumpulan data pustaka, membaca dan mencatat serta mengelola bahan penelitian kemudian peneliti menyimpulkan bahan penelitian yang sudah dikelola sebelumnya. Ada 3 alasan mengapa menggunakan penelitian pustaka yaitu: 1) persoalan penelitian tersebut hanya bisa dijawab lewat penelitian pustaka, 2) studi pustaka diperlukan

sebagai salah satu tahap tersendiri, yaitu studi pendahuluan untuk memahami lebih dalam gejala baru yang tengah berkembang di lapangan atau dalam masyarakat, 3) data pustaka tetap andal untuk menjawab persoalan penelitiannya. Dengan demikan, riset pustaka dengan cara memanfaatkan sumber perpustakaan untuk memperoleh data penelitiannya sehingga dengan riset pustaa dapat membatasi kegiatan hanya pada bahan- bahan koleksi perpustakaan tanpa memerlukan riset lapangan.

\section{HASIL DAN PEMBAHASAN}

\section{Hubungan Metode Mendongeng dengan Kemampuan Berbahasa pada Anak Usia Dini}

Penelitian yang mendukung bahwa peningkatan kemampuan bahasa dapat didapat dari pemberian dongeng adalah penelitian yang dilakukan oleh Lamuningtyas (2012) yang membuktikan bahwa adanya peningkatan kemampuan bahasa yang sangat signifikan. Aspek kemampuan bahasa yang diteliti adalah kemampuan menyimak, berbicara, membaca, dan menulis. Keempat aspek ini dinilai sangat penting untuk digunakan sebagai sarana komunikasi. Hal ini membuktikan bahwa bahasa memegang peranan penting dalam kehidupan manusia dan salah satu metode pengembangan yang dilakukan pada anak usia prasekolah adalah dengan mendongeng atau bercerita. Lamuningtyas (2012) juga mengatakan dalam penelitiannya bahwa tanpa bahasa 
anak tidak dapat atau akan mengalami kesulitan saat berkomunikasi dengan orang lain, ia juga mengatakan bahwa dengan bahasa anak dapat mengekspresikan pikirannya sehingga orang-orang yang berada disekitarnya akan memahami apa yang dipikirkan oleh anak.

Selain itu penambahan kosakata baru dapat dilakukan dengan pembawa cerita menunjuk langsung alat peraga atau mempraktikkan langsung suatu perilaku, sehingga anak dapat melihat secara langsung. Hal ini dinilai sangat mencontoh sebuah perilaku orang tua yang dilihatnya. Penyampaian pesan moral yang terkandung dalam cerita akan lebih mudah melekat didalam benak anakanak, karena dengan metode bercerita dinilai lebih menarik dan berkesan bagi anak. Sehingga anak lebih merasa senang dalam menerima pesan moral tersebut dibandingkan dengan pemberian nasehat yang dinilai menjenuhkan bagi anak (Fauziddin, 2014).

Dengan adanya penambahan perbendaharaan kata maka hal ini akan menunjang kemampuan bahasa yang dapat digunakan anak untuk berkomunikasi dengan orang lain serta mengekspresikan perasaannya, maka sangatlah penting untuk memberikan pengajaran pada anak terkait penyampaian informasi dengan struktur bahasa yang baik. Karenanya metode mendengarkan dongeng dinilai sangat efektif untuk dijadikan sebuah metode pembelajaran pengembangan kemampuan bahasa anak. Mendengarkan dongeng mencakup penambahan kosakata baru dalam unsur cerita juga pesan moral, sehingga dengan metode ini anak dengan mudah menerima penambahan kosakata baru dan juga pesan moral yang terkandung dalam sebuah cerita (Wiyani, 2014).

Penelitian serupa juga dilakukan oleh Roointan dan Mousavi (2014) yang menyatakan bahwa metode bercerita memiliki dampak pada kecerdasan verbal dan koskata anak prasekolah. Hasil penelitiannya menunjukkan bahwa mengajar melalui bercerita mempengaruhi kecerdasan verbal anak beserta komponen-komponennya yang termasuk dalam kosa kata, kesamaan, informasi, perhitungan, dan pemahaman. Banyak psikolog yang percaya bahwa kemampuan bahasa banyak membantu anak-anak dalam pertumbuhan mental, para psikolog menemukan bahwa bercerita memainkan peran penting dalam pemahaman dan anak-anak dapat memperoleh lebih banyak kata dalam percakapan sehari-hari dan memahami lebih banyak makna kata.

Aziz dkk (2003:6) mengungkapkan apabila dilihat dari isi ceritanya dongeng mempunyai kekuatan dalam membangun imajinasi anak, menanamkan nilai-nilai etika, menanamkan rasa simpati, rasa kesetiakawanan pada sesama, yang akhirnya akan membentuk kepribadian pada seorang anak. Jadi dongeng mempunyai fungsi bukan sekedar alat komunikasi tetapi juga alat menanamkan nilai.

Dari beberapa hasil penelitian yang telah dilakukan maka dapat disimpulkan bahwa metode mendongeng atau bercerita dapat meningkatkan kemampuan berbahasa anak. Karena melalui kegiatan mendengarkan, anak dapat secara langsung menyerap informasi yang diterima melalui penutur. Hal ini tentunya juga akan mempengaruhi pemerolehan bahasa anak seperti penguasaan kosakata baru sehingga anak dapat berkomunikasi dan mengekspresikan perasaannya kepada orang lain. Metode mendongeng atau bercerita juga merupakan salah satu metode alternatif yang dapat mengembangkan kemampuan berbahasa anak dan memang sesuai dengan tingkat pekembangan anak usia dini. Karena pada usia ini, aspek kemampuan bahasa yang lebih dikembangkan adalah kemampuan menyimak ataupun mendengarkan.

\section{Hubungan Metode Mendongeng dengan Penanaman Moral pada Anak Usia Dini}

Dalam pendidikan anak usia dini salah satu kawasan yang harus dikembangkan adalah nilai moral, karena dengan diberikannya pendidikan nilai dan 
moral sejak usia dini, diharapkan pada tahap perkembangan selanjutnya anak akan mampu membedakan baik buruk, benar salah, sehingga ia dapat menerapkannya dalam kehidupan sehariharinya. Ini akan berpengaruh pada mudah tidaknya anak diterima oleh masyarakat sekitarnya dalam hal bersosialisasi. Dalam pengembangan nilai moral anak usia dini harus dilakukan dengan tepat. Jika hal ini tidak bisa tercapai, maka pesan moral yang akan disampaikan "orang tua kepada anak menjadi terhambat. Pengembangan nilai moral untuk anak usia dini ini bisa dilakukan di dalam tiga tri pusat pendidikan yang ada, yaitu keluarga, sekolahh dan masyarakat.

Dalam pengembangan nilai moral untuk anak usia dini perlu dilakukan dengan sangat hati-hati. Hal ini dikarenakan anak usia dini adalah anak yang sedang dalam tahap perkembangan pra operasional kongkrit seperti yang dikemukakan oleh Piaget, sedangkan nilai-nilai moral merupakan konsepkonsep yang abstrak, sehingga dalam hal ini anak belum bisa dengan serta merta menerima apa yang diajarkan guru/orang tua yang sifatnya abstrak secara cepat. Untuk itulah "orang tua" harus pandaipandai dalam memilih dan menentukan metode yang akan digunakan untuk menanamkan nilai moral kepada anak agar pesan moral yang ingin disampaikan guru dapat benar-benar sampai dan dipahami oleh siswa untuk bekal kehidupannya di masa depan.

Perkembangan moral anak sangat ditentukan sejak usia dini, karena anak masih belajar mengenal kejadian atau peristiwa yang ditemuinya dan mulai belajar dari peristiwa itu. Oleh karena itu, diperlukan trik-trik atau kiat khusus agar anak dapat belajar dan mengambil nilai positif dari setiap kejadian yang terjadi. Berkaitan dengan hal ini, mendongeng bisa menjadi saah satu alternatif untuk menanamkan moral pada anak. Karena melalui cerita atau dongeng yang disampaikan dapat memberikan pesan moral dan ajaran-ajaran budi pekerti bagi pendengarnya.
Anak yang secara tidak langsung mendengarkan cerita atau dongeng akan dapat mengungkapkan imajinasi dan pikiran mereka dengan bemain dan bergembira. Selain itu dongeng juga dapat memberikan dampak positif bagi kemampuan emosi pada anak sehingga dapat membentuk sikap kreatif, ramah, mudah bergaul dan terbangun empati baik pada lingkungan maupun orang disekitarnya.

Menurut Musfiroh (2009: 29) adalah salah satu upaya untuk menanamkan nilainilai budi pekerti atau nilai-nilai karakter. Nilai-nilai itu adalah moral, budi pekerti, kejujuran, kebaikan, kemandirian, keagamaan dll, bisa ditanamkan pada anak-anak, melalui bercerita pula anakanak dapat belajar mengembangkan imajinasi, mengekspresikan diri, dan dapat memetik hikmah dari cerita tersebut. Bercerita mendorong anak memberikan makna bagi proses belajar terutama mengenai empati, dan dari kehadiran cerita membuat anak lebih joy in school dan memiliki kerinduan bersekolah.

Manfaat-manfaat cerita bagi anak usia dini adalah (1) membangun kontak batin antara anak, guru dan orang tuanya, (2) media penyampai pesan terhadap anak, (3) pendidikan imajinasi atau fantasi anak, (4) dapat melatih emosi atau perasaan anak, (5) membantu proses identifikasi diri, (6) memperkaya pengalaman batin, (7) dapat sebagai hiburan atau menarik perhatian anak, (8) dapat membentuk karakter anak (Fadlillah 174:2012).

Melalui mendongeng maka secara otomatis akan terjadi transformasi nilai melalui tingkah laku dan karakter tokoh yang ada dalam cerita. Ditambah lagi jika dalam mendongeng dibantu dengan menggunakan alat teknologi canggih maka suasana mendongeng akan menjadi lebih hidup.

Dari beberapa pendapat yang telah dipaparkan, dapat disimpulkan bahwa metode mendongeng merupakan salah satu cara ampuh dalam menanamkan moral pada anak usia dini. Karena secara tidak langsung melalui kegiatan mendengarkan/menyimak yang dilakukan 
dapat memberikan dampak positif bagi kemampuan emosi anak sehingga dapat membentuk sikap yang baik bagi anak.

Selain itu, peran tokoh yang ada pada cerita juga dapat membuat anak berimajinasi agar dapat meniru karakter yang dimainkan oleh setiap tokohnya dan tentunya peran tokoh yang dapat menjadi panutan yang baik bagi anak.

\section{UCAPAN TERIMA KASIH}

Terima kasih penulis ucapkan kepada Tim Editor E-Journal Obsesi yang sudah memberikan kesempatan sehingga jurnal ini siap untuk diterbitkan, tidak lupa pula saya ucapkan rangkaian terima kasih yang sebesar besarnya kepada reviewer yang sudah mau meluangkan waktunya untuk mereview serta memberikan banyak masukan sehingga jurnal ini lebih sempurna. Untuk semua teman sejawat dosen dosen Universitas Pahlawan Tuanku Tambusai yang telah memberikan semangat dalam penulisan ini sehingga penulis dapat menyelesaikan tepat pada waktunya.

\section{SIMPULAN}

Pada hakikatnya pendidikan anak usia dini adalah pemberian upaya dalam membimbing, mendidik dan memberi stimulus dalam pembelajaran melalui kegiatan yang menyenangkan. Salah satu pekembangan yang harus difasilitasi oleh guru adalah pekembangan bahasa serta penanaman moral pada anak melalui metode mendongeng. Mendengarkan dongeng mencakup penambahan kosakata baru dalam unsur cerita juga pesan moral, sehingga dengan metode ini anak dengan mudah menerima penambahan kosakata baru dan juga pesan moral yang terkandung dalam sebuah cerita Melalui mendongeng maka secara otomatis akan terjadi transformasi nilai melalui tingkah laku dan karakter tokoh yang ada dalam cerita

\section{DAFTAR PUSTAKA}

Agus, D.S. 2008. Mendongeng Bareng Kak Agus D.S Yuk. Yogyakarta: Kanisius

Alwi, Hasan. 2007. KBBI, edisi ketiga. Jakarta: Balai Pustaka.

Aziz M, dkk. 2003. Sepasang Burung dan Nabi Sulaiman. Yogyakarta: Mitra Pustaka

Berns, R.M. (1997). Child, Family, School, Community: Socialization And Support. USA (US): Rinehart and Winston, Inc.

Bertens, K, 1993. Etika. Jakarta: PT Gramedia Pustaka Utama

Danandjaja, J. (1994). Folklor Indonesia, ilmu gosip, dongeng, dan lain-lain (cet.

Keempat). Jakarta: PT. Pustaka Utama Grafiti.

Eni Zubaidah. (2003). Pengembangan Bahasa Anak Usia Dini. Yogyakarta: FIP UNY

Fadlillah, M. (2012). Desain Pembelajaran PAUD. Jogjakarta : AR-RUZZ MEDIA

Fauziddin, M. (2014). Pembelajaran PAUD bermain, cerita, dan bernyanyi secara islami. Bandung: Rosdakarya

Hurlock, E.B. (1978). Perkembangan anak jilid 1 edisi keenam. Jakarta: Erlangga.

Jahja, Y. (2011). Psikologi Perkembangan. Jakarta: Prenada Media Grup

Kartini Kartono. 1995. Psikologi Anak (Psikologi Perkembangan). Bandung : CV Mandar Maju.

Lamuningtyas, Y.A. (2012). Pemberian dongeng untuk meningkatkan kemampuan bahasa pada anak usia prasekolah. Skripsi, Tidak dipublikasikan 
Mansur. 2005. Pendidikan Anak Usia Dini Dalam Islam. Yogyakarta: Pustaka Pelajar

Mohammad Ali, dkk. 2012. Psikologi Remaja, Perkembangan Peserta Didik. PT Bumi Aksara: Jakarta

Musfiroh, T. (2009). Bercerita untuk Anak Usia Dini. Jakarta: Depdiknas

Nurgiyantoro (2005) . Sastra Anak : Pengantar Pemahaman Dunia Anak. Yogyakarta : Universitas Gajah Mada.

Roointan, Z., \& Mousavi, F. (2014). Investigation of the influence of teaching via story-telling on verbal intelligence and vocabulary of preshoolers (case study: SarPol_Zabhab City, 20132014).J.appl.environ.biol.sci, 4(12)127- 132, 2014 (C)2014, Test Road Publication.

Rusdinal,dkk. (2005). Pengelolaan Kelas di Taman Kanak-kanak. Jakarta : Depdiknas Dikjen Pendidikan Tinggi Direktorat Pembinaan Pendidikan Tenaga Kependidikan Dan Ketenagaan Perguruan Tinggi

Santrock, J.W. (2011). Masa perkembangan anak buku 1 edisi 11. Jakarta: Salemba. Humanika

Suhartono. 2005. Pengembangan keterampilan bicara anak usia dini. Jakarta: Depdiknas.

Suyanto, 2005. Konsep Dasar Anak Usia Dini : Jakarta : Departemen Pendidikan Nasional.

Upton, P. (2012). Psikologi perkembangan. Jakarta: Penerbit Erlangga.

Wiyani, N.A. (2014). Psikologi perkembangan anak usia dini panduan bagi orang tua dan pendidik PAUD dalam memahami serta mendidik anak usia dini. Yogyakarta: Penerbit Gava Media.
Zed, Mestika. 2004. Metode Penelitian Kepustakaan. Jakarta: Yayasan Obor. Indonesia. 